\title{
STRUKTUR DAN KOMPOSISI VEGETASI DI ARBORETUM SUNGAI GERONG PT. PERTA SAMTAN GAS, KABUPATEN BANYUASIN, PROVINSI SUMATERA SELATAN
}

\section{(Structure and Vegetation Composition in Arboretum River Forest in PT. Perta Samtan Gas, Banyuasin District, South Sumatera Province)}

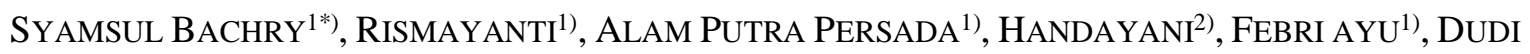 \\ LESMANA $^{3)}$, ALMUJIZAT ${ }^{4}$ DAN ANDIKA ${ }^{5)}$
}

1) Program Studi Biosains Hewan, Fakultas Matematika dan Ilmu Pengetahuan Alam, Kampus IPB Dramaga, Bogor 16680, Indonesia

2) Program Biologi, Fakultas Sains dan Teknologi, Universitas Islam As-Syafi 'iyah, Jakarta Timur, 13070, Indonesia

3) Shared Value Indonesia, Pejaten Timur, Jakarta Selatan, 12510, Indonesia

4) Indonesia Shared Value Institute, Kembangan Jakarta Barat, 11610, Indonesia

5) PT. Perta-Samntan Gas, Banyuasin, Palembang, 30967, Indonesia

*Email: syamsulbachry69@yahoo.com

Diterima 03 Januari 2020 / Disetujui 24 Juli 2020

\begin{abstract}
Forest characteristics are very complex with various types of components, and one of which is the arboretum type. PT. Perta Samtan Gas Pertamina has designated arboretrum as a buffer zone which functions to protect its flora and fauna. This study aims to determine the diversity of vegetation types and compositions in the Gerong River Arboretum of PT. Perta Samtan Gas, Banyuasin Regency, South Sumatra Province. Data collection were carried out by collecting data on the diversity of vegetation types. Each transect line within the ecosystem type has a size of $20 \mathrm{~m} x 60$ $m$. The transect is then divided into sub-plots using the nested sampling method. There are 23 types of vegetation in the Gerong River Arboretum area. The distribution and density of vegetation that was mostly found was Spathodea campanulate with an important value index of $185.87 \%$ at the tree level, while at the pile and sapling level the most commonly found were Calophyllum tetrapterum with IVIs of 118.29\% and 77.859\%. The level of seedlings found was Nephrolepis falciformis with an IVI value of $26.45 \%$. The diversity of vegetation types in the Gerong River Arboretum area is moderate and the evenness is good, only a few types of vegetation dominate in this observation..
\end{abstract}

Keywords: Banyuasin, Gerong River Arboretum, important value index, species diversity, vegetation structure

\section{ABSTRAK}

Karakteristik hutan sangat kompleks dengan berbagai tipe penyusunnya, salah satunya adalah tipe arboretum. Arboretum PT. Perta Samtan Gas Pertamina merupakan salah satu zona penyangga (buffer zone) yang berfungsi sebagai kawasan konservasi untuk flora dan fauna yang ada di dalamnya. Penelitian ini bertujuan untuk mengetahui keragaman jenis dan komposisi vegetasi di Arboretum Sungai Gerong PT. Perta Samtan Gas, Kabupaten Banyuasin, Provinsi Sumatera Selatan. Pengambilan data dilaksanakan dengan mengumpulkan data keanekaragaman jenis vegetasi. Setiap jalur pada tipe ekosistem memiliki ukuran $20 \mathrm{~m}$ x $60 \mathrm{~m}$. Jalur tersebut kemudian dibagi menjadi subpetak menggunakan metode nested sampling. Terdapat 23 jenis vegetasi pada wilayah Arboretum Sungai Gerong. Sebaran dan kerapatan vegetasi yang banyak ditemukan adalah Spathodea campanulate dengan indeks nilai penting sebesar 185,87\% pada tingkat pohon, sedangkan pada tingkat tiang dan pancang yang banyak ditemukan adalah Calophyllum tetrapterum dengan INP sebesar 118,29\% dan 77,859\%. Tingkat semai yang banyak ditemukan adalah Nephrolepis falciformis dengan INP sebesar 26,45\%. Keanekaragaman jenis vegetasi di wilayah Arboretum Sungai Gerong tergolong sedang dan kemerataan tergolong baik, hanya sedikit jenis vegetasi yang mendominasi pada pengamatan ini.

Kata kunci: Arboretum Sungai Gerong, Banyuasin, indeks nilai penting, keragaman jenis, struktur vegetasi

\section{PENDAHULUAN}

Keanekaragaman hayati (biodiversity) adalah komponen-komponen dari abiotik dan biotik dengan berbagai sumbernya dari daratan, lautan dan ekosistem akuatik lain, keanekaragaman hayati tersusun dari tingkatan yang berbeda yaitu keanekaragaman genetik, keanekaragaman spesies dan keanekaragaman ekosistem (Primack et al. 1998). Tipe ekosistem hutan Indonesia adalah tipe hutan hujan tropis dengan curah hujan sepanjang tahun. Oleh karena itu, kondisi alam tersebut menciptakan habitat yang ideal bagi keberlangsungan kehidupan fauna dan flora.

Pengelolaan akan keanekaragaman hayati pada pembangunan berkelanjutan (sustainable development) sangat penting di bidang industri, kesehatan, pertanian dan ilmu pengetahuan. Nilai guna akan keanekaragaman hayati sangat besar kontribusinya dalam kehidupan manusia. Suhendang (2002) menyatakan bahwa perlu 
adanya pengelolaan sumber daya hutan dengan baik dan terarah sehingga fungsi dan kualitas hutan tersebut terjaga secara terus menerus.

Di era modern sekarang, teknologi perusahaan semakin maju dan berkembang pesat dikhawatirkan akan berdampak terhadap lingkungan dan keanekaragaman hayati di sekitarnya. Dengan demikian untuk mentolerir atau mengurangi kerusakan yang ditimbulkan maka pelestarian harus dilakukan dengan aturan sesuai dengan pedoman konservasi keanekargaman hayati dan ekosistemnya. Salah satu kawasan hutan yang berfungsi sebagai pelestarian keanekaragaman hayati adalah Arboretum.

Kawasan arboretum merupakan kawasan hutan koleksi pepohonan dengan luasan tertentu yang berisi berbagai jenis pohon baik yang sudah ada maupun yang ditanam dengan mengikuti habitat aslinya serta dimaksudkan sebagai areal pelestarian keanekaragaman hayati (Nopolion et al. 2015). Arboretum juga memiliki peranan dalam ekowisata, sarana pendidikan, penelitian dan pengembangan.

Struktur dan komposisi vegetasi adalah hasil penantaan ruang dari komponen penyusun tegakan dan bentuk hidup, stratifikasi, dan penutupan vegetasi yang digambarkan melalui keadaan diameter, tinggi, penyebaran dalam ruang, keanekaragaman tajuk, serta kesinambungan jenis (Fachrul 2007). Komposisi vegetasi dapat diartikan sebagai keragaman jenis dalam tegakan hutan (Oktaviani et al. 2017). Beberapa penelitian mengenai struktur dan komposisi vegetasi di antaranya Gunawan et al. (2011) di kawasan hutan Taman Nasional
Gunung Pangrango; Cahyanto et al. (2014) di hutan alam Gunung Manglayang, Kabupaten Bandung; Sidiyasa (2009) di hutan lindung sungai Wain, Balikpapan, Kalimantan Timur. Penelitian tentang struktur dan komposisi sudah banyak dilakukan di kawasan hutan alam, akan tetapi untuk arboretum belum banyak dilaporkan.

Perusahan PT Perta Samtan Gas kilang fraksinasi, memiliki kawasan Arboretum dengan luas wilayah 10.810,23 $\mathrm{m}^{2}$ yang berada di Desa Sungai Gerong Kabupaten Banyuasin. Kawasan ini memliki peran penting dalam perlindungan fungsi hidrologis dan keanekaragaman hayati. Penelitian mengenai komposisi dan struktur vegetasi Arboretum Sungai Gerong belum pernah dilaporkan. Oleh karena itu penting untuk dilakukan kajian mengenai struktur dan komposisi vegetasi khususnya di Arboretum Sungai Gerong yang berfungsi sebagai data dasar pengelolaan kawasan tersebut.

\section{METODE PENELITIAN}

Penelitian dilaksanakan pada Agustus 2019. Lokasi penelitian di wilayah Arboretum Sungai Gerong, Kabupaten Banyuasin, Provinsi Sumatera Selatan (Gambar 1). Wilayah tersebut adalah kawasan konservasi keanekaragaman hayati yang dikembangkan oleh perusahaan gas PT. Perta Samtan Gas kilang fraksinasi, Pertamina.

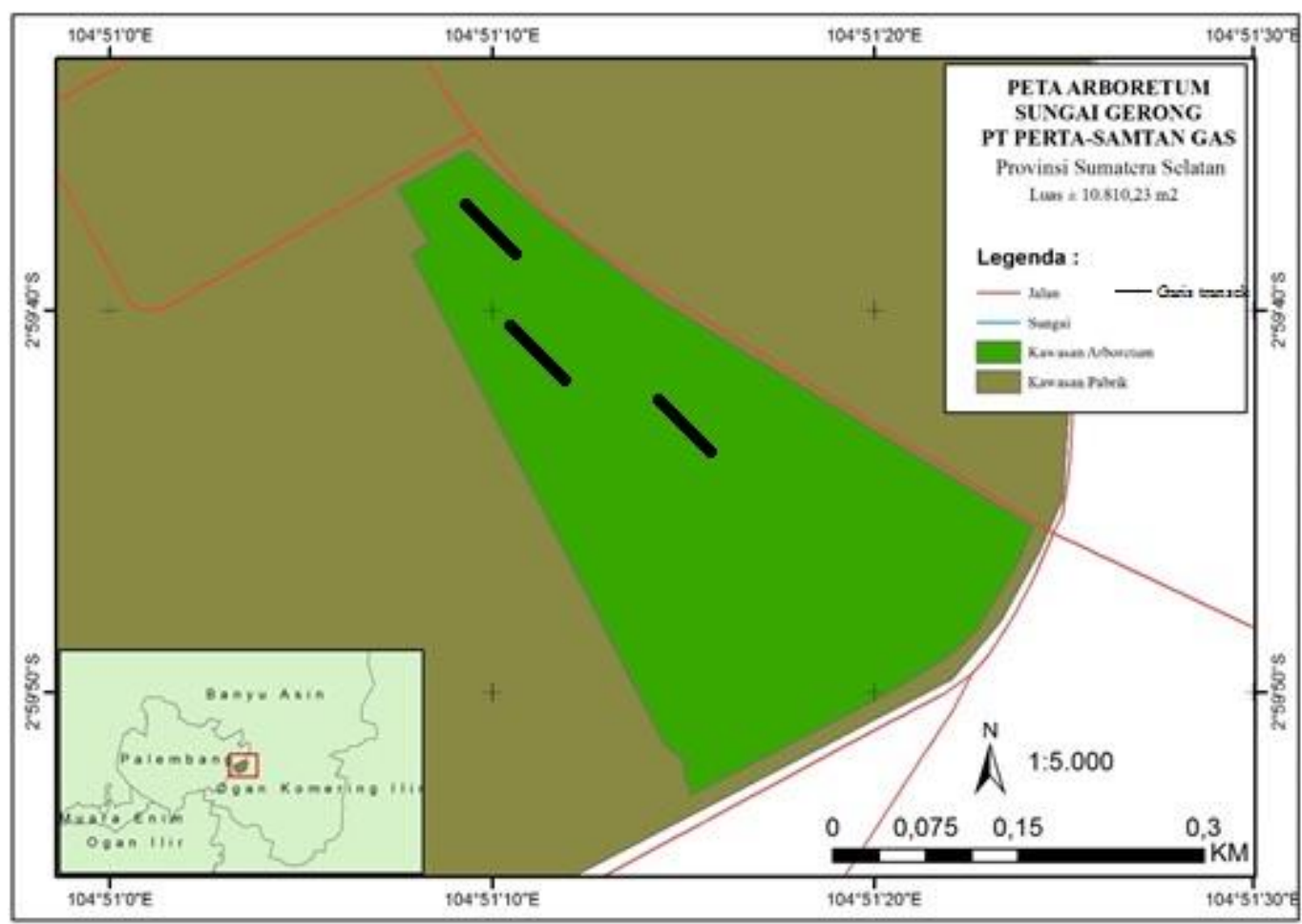

Gambar 1. Lokasi penelitian 
Peralatan dan bahan yang digunakan yaitu meteran jahit, pita ukur, kertas koran, sasak kayu, Haga hypsometer untuk mengukur tinggi pohon, alkohol untuk pembuatan herbarium, thermohygrometer untuk mengukur kelembaban dan udara, meteran $50 \mathrm{~m}$, tali tambang, Global Positioning System (GPS) untuk menentukan titik koordinat lokasi, alat tulis, plastik klip ukuran 30x40, parang, buku identifikasi jenis flora, tallysheet flora, dan kamera digital.

Analisis vegetasi dilakukan untuk menentukan Kerapatan Relatif (KR), Frekuensi Relatif (FR) dan Dominasi Relatif yang selanjutnya digunakan untuk menentukan Indeks Nilai Penting (INP) (MuellerDombois dan Ellenberg 1974). Vegetasi yang dianalisis terdiri dari tingkat pohon, tiang, pancang dan semai.

Data yang dikumpulkan meliputi struktur dan komposisi vegetasi. Kawasan Arboretum termasuk tipe ekosistem hutan sekunder, hal ini terkait bahwa arboretum tersebut tumbuh secara alami dan dibentuk menjadi kawasan arboretum oleh pihak PT. Perta Samtan Gas, Banyuasin sebagai kawasan konservasi lingkungan. Pembentukan jalur dilakukan berdasarkan survei kondisi di lapangan, hal ini terkait dengan ekositem hutan arboretum tersebut. Pendatan vegetasi terbagi menjadi tiga jalur dengan masing-masing transek pada tipe ekosistem memiliki ukuran $20 \mathrm{~m}$ x $60 \mathrm{~m}$. Transek tersebut kemudian dibagi menjadi subpetak menggunakan metode nested sampling. Ukuran luas petak contoh disesuaikan dengan pertumbuhan vegetasi yaitu semai $2 \mathrm{~m}$ x $2 \mathrm{~m}$, pancang $5 \mathrm{~m} \mathrm{x} 5 \mathrm{~m}$, tiang $10 \mathrm{~m} \mathrm{x}$ $10 \mathrm{~m}$, dan pohon $20 \mathrm{~m}$ x $20 \mathrm{~m}$ (Gambar 2). Adapun variabel yang diamati pada semai yaitu jenis, jumlah individu tiap jenis; pancang: jenis, jumlah individu tiap jenis, ukuran lingkaran atau diameter setinggi dada (dbh); tiang: jenis, ukuran lingkaran atau diameter setinggi dada (dbh), tinggi; dan pohon: jenis, ukuran lingkaran atau diameter setinggi dada (dbh), tinggi.

Data yang diperoleh dianalisis berdasarkan rumus perhitungan, Indeks Nilai Penting (INP), yang dikutip dari Soerianegara dan Indrawan (2016):

- Indeks Nilai Penting (INP) untuk, pancang, tiang dan pohon $=\mathrm{KR}+\mathrm{FR}+\mathrm{DR}$;

- Indeks Nilai Penting (INP) untuk semai atau tumbuhan non pohon $=\mathrm{KR}+\mathrm{FR}$.

Setiap jenis vegetasi dihitung Kerapatan (K), Kerapatan Relatif (KR), Frekuensi (F), Frekuensi Relatif (FR), Dominansi (D), dan Dominansi Relatif (DR) dengan rumus di bawah ini:

$$
\begin{aligned}
& \text { Kerapatan jenis }(\mathrm{K})=\frac{\text { Jumlah individusuatujenis }}{\text { Iuas plot pangamatan }} \times 100 \% \\
& \text { Kerapatan relatif }(\mathrm{KR})=\frac{\text { Kerapatan suatujenis }}{\text { Kerapatan seluruhjenis }} \times 100 \% \\
& \text { Frekuensi jenis }(\mathrm{K})=\frac{\text { Jumlahplot ditemukannya suatujenis }}{\text { Jumlah total plot pengamatan }} \times 100 \% \\
& \text { Frekuensi relatif (KR) }=\frac{\text { Frekuensi suatujeris }}{\text { Frekuensi seluruhjenis }} x 100 \% \\
& \text { Dominasi relatif (KR) }=\frac{\text { Dominasi suatujenis }}{\text { Dominasi seluruhjenis }} x 100 \%
\end{aligned}
$$

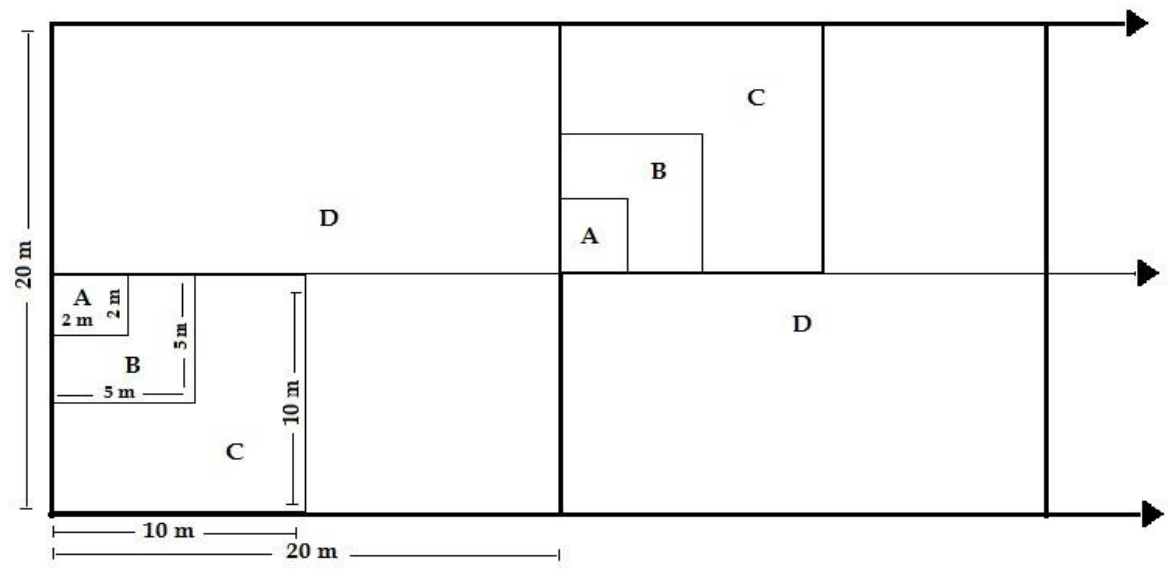

Gambar 2 Desain plot pengambilan sampel

Keterangan: (A) Plot tingkat semai (permudaan dengan tinggi $<1,5 \mathrm{~m}$ ) dan tumbuhan bawah (herba, terna, semak, dan perdu), (B) Tingkat pancang (tinggi $>1,5 \mathrm{~m}$ dan diameter $<10 \mathrm{~cm}$ ) dan palem, (C) Tingkat tiang (pohon muda berdiameter 10-20 cm), (D) Tingkat pohon (pohon berdiameter > $20 \mathrm{~cm}$ ) (Odum 1971; Misra 1980; Ludwig dan Rey-nolds 1988). 
Untuk mengetahui derajat keanekaragaman jenis vegetasi digunakan rumus:

$$
\mathrm{H}^{\prime}=-\sum_{i=1}^{s}\left[\left(\frac{n i}{N}\right) \ln \left(\frac{n i}{N}\right)\right]
$$

Keterangan:

H': indeks keanekaragaman

pi : ni / N

ni : jumlah genus jenis ke-i

$\mathrm{N}$ : jumlah total genus ke- $\mathrm{i}$

Nilai indeks keanekaragaman ini kemudian dikelompokkan secara empiris menjadi:

$\mathrm{H}^{\prime} \leq 1=$ Keanekaragaman rendah (stabilitas rendah)

$1<\mathrm{H}^{\prime}<3=$ Keanekaragaman sedang (stabilitas sedang)

H' $\geq 3$ = Keanekaragaman tinggi (stabilitas tinggi)

Indeks keseragaman digunakan untuk mengetahui tingkat kemerataan jenis vegetasi (Krebs 1989), dengan persamaan sebagai berikut :

$$
\mathrm{E}=\frac{\mathrm{H}^{\circ}}{\ln (\mathrm{S})}
$$

Keterangan :

$\mathrm{E}$ : indeks kemerataan

$\mathrm{H}^{\prime}$ : indeks keanekaragaman

$\mathrm{S}$ : jumlah genus

Dengan kriteria:

$\mathrm{E} \sim 0$ : terdapat dominansi spesies

$\mathrm{E} \sim 1$ : jumlah individu tiap spesies sama

Untuk mengetahui kekayaan jenis vegetasi dengan rumus:

Keterangan:

$$
\operatorname{Dmg}=\frac{\mathrm{S}-1}{\ln (\mathrm{N})}
$$

Dmg : Indeks kekayaan jenis

$\mathrm{S} \quad$ : Jumlah jenis spesies

$\mathrm{N}$ : Total jumlah individu spesies

\section{HASIL DAN PEMBAHASAN}

\section{Sebaran dan Kerapatan Jenis Vegetasi di Arboretum Sungai Gerong}

Arboretum Sungai Gerong adalah tipe hutan sekunder yang masih terlindungi. Spesies Bungur atau Spathodea campanulate adalah jenis yang dominan di temukan pada areal ini, selain itu terdapat jenis Ficus $c f$. aamptophylla. Dwisutono et al. (2019) menyatakan bahwa keberadaan tumbuhan Ficus spp. sangat bereran sebagai daya tarik spesies satwa dalam keberlangsungan suatu ekosistem. Sebaran dan kerapatan vegetasi di kawasan arboretum sangat kompleks, hal ini karena ditemukan jenis vegetasi mulai tingkat semai, pancang, tiang dan pohon. Kerapatan vegetasi dalam pengamatan dinyatakan dalam hektar. Sedangkan sebaran vegetasi berdasarkan jumlah individu jenis dalam luasan suatu area.

Hasil penelitian pada tingkat pohon menunjukkan bahwa transek dua memiliki jumlah yang terbesar sebanyak 75 ind/ha, adapun yang terkecil ditemukan di transek satu dengan jumlah 16,67 ind/ha. Pada tingkat tiang yang memiliki jumlah terbanyak yaitu transek dua dengan jumlah tegakan 200 ind/ha dan transek tiga adalah yang terendah dengan jumlah tegakan sebanyak $100 \mathrm{ind} / \mathrm{ha}$. Tingkat pancang yang terbesar pada transek tiga dengan jumlah 2.400 ind/ha dan jumlah individu terkecil ditemukan pada transek satu sebesar 933 ind/ha. Pada tingkat semai menunjukkan jumlah yang tertinggi di transek tiga dengan nilai 80.833 ind/ha dan terkecil ditemukan di transek satu dengan jumlah $4167 \mathrm{ind} / \mathrm{ha}$ (Tabel 1).

\section{Komposisi Vegetasi}

Komposisi jenis suatu taksa atau habitus tumbuhan dapat diketahui dengan melakukkan analisis vegetasi (Locky and Bayley 2006). Berdasarkan hasil pengamatan ditemukan 23 jenis yang terdiri dari 17 famili. Komposisi jenis yang ditemukan pada jalur pengamatan penelitian dilakukan perhitungan INP. Nilai INP pada tumbuhan berbagai tingkat pertumbuhan dapat dilihat pada Tabel 2 sampai 5.

Dari hasil pengamatan menunjukkan komposisi vegetasi penyusun Arboretum Sungai Gerong terdiri dari sepuluh jenis yang termasuk kedalam klasifikasi vegetasi di antaranya Spathodea campanulata, Ficus cf. acamptophylla, Bridelia tomentosa, Calophyllum tetrapterum, Syzygium sumatranum, Vitex pinnata, Lindera insignis, Xylopia malayana, Pseuderanthemum sumatrense, Microcos tomentosa, sedangkan vegetasi semai sebanyak 13 jenis. Komposisi vegetasi jenis Spathodea campanulata dengan INP sebesar 185,87\% untuk kategori pohon (Tabel 2). Vegetasi jenis Calophyllum tetrapterum dengan INP sebesar 118,29\% untuk kategori tiang (Tabel 3), begitupun vegetasi pancang dengan INP sebesar 77,859\% (Tabel 4). Selanjutnya vegetasi tingkat semai didominasi jenis Nephrolepis falciformis dengan INP sebesar 26,45\% (Tabel 5).

Tabel 1 Klasifikasi jumlah tegakan di Arboretum Sungai Gerong

\begin{tabular}{lccc}
\hline \multicolumn{1}{c}{ Klasifikasi } & \multicolumn{3}{c}{ Jumlah Tegakan (ind/ha) } \\
\cline { 2 - 4 } & Transek satu & Transek dua & Transek tiga \\
\hline Vegetasi pohon & 16,67 & 75 & 25 \\
Vegetasi tiang & 133 & 200 & 100 \\
Vegetasis pancang & 933 & 2.267 & 2.400 \\
Vegetasi semai & 4.167 & 10.833 & 80.833 \\
\hline
\end{tabular}


Tabel 2 Indeks nilai penting pohon di kawasan Arboretum Sungai Gerong

\begin{tabular}{rccccccccc}
\hline No & Jenis vegetasi & $\mathrm{n}$ & $\mathrm{K}(\%)$ & $\mathrm{KR}(\%)$ & $\mathrm{F}(\%)$ & $\mathrm{FR}(\%)$ & $\mathrm{D}(\%)$ & DR $(\%)$ & $\mathrm{INP}(\%)$ \\
\hline 1 & Ficus cf. acamptophylla & 3 & 25 & 23,08 & 0,67 & 50,00 & $10.4780,4$ & 41,06 & 114,13 \\
2 & Spathodea campanulata & 10 & 83,33 & 76,92 & 0,67 & 50,00 & $15.0427,3$ & 58,94 & 185,87 \\
\hline \multicolumn{2}{r}{ Total } & 13 & 108,3 & 100 & 1,33 & 100 & $255.207,7$ & 100 & 300 \\
\hline
\end{tabular}

Tabel 3 Indeks nilai penting tiang di kawasan Arboretum Sungai Gerong

\begin{tabular}{|c|c|c|c|c|c|c|c|c|c|}
\hline No & Jenis vegetasi & $\mathrm{n}$ & $\mathrm{K}(\%)$ & $\mathrm{KR}(\%)$ & $\mathrm{F}(\%)$ & $\mathrm{FR}(\%)$ & $\mathrm{D}(\%)$ & DR $(\%)$ & $\operatorname{INP}(\%)$ \\
\hline 1 & Bridelia tomentosa & & 100,0 & & & & & & \\
\hline & & 3 & & 23,08 & 1,00 & 33,3 & $14.997,35$ & 25,36 & 81,77 \\
\hline 2 & Spathodea campanulata & & 133,3 & & & & & & \\
\hline \multirow{5}{*}{3} & & 4 & & 30,77 & 1,00 & 33,3 & $21.196,92$ & 35,84 & 99,94 \\
\hline & Calophyllum & & 200,0 & & & & & & \\
\hline & tetrapterum & 6 & & 46,15 & 1,00 & 33,3 & $22.948,51$ & 38,80 & 118,29 \\
\hline & & & 433,3 & & & & & & \\
\hline & Total & 13 & & 100,00 & 3,00 & 100,00 & $59.142,78$ & 100,00 & 300,00 \\
\hline
\end{tabular}

Tabel 4 Indeks nilai penting pancang di kawasan Arboretum Sungai Gerong

\begin{tabular}{|c|c|c|c|c|c|c|c|c|c|}
\hline No & Jenis vegetasi & $\mathrm{n}$ & $\mathrm{K}(\%)$ & $\mathrm{KR}(\%)$ & $\mathrm{F}(\%)$ & FR $(\%)$ & $\mathrm{D}(\%)$ & $\mathrm{DR}(\%)$ & INP $(\%)$ \\
\hline 1 & Ficus cf. acamptophylla & 1 & 133 & 2,381 & 0,091 & 6,25 & $113.234,3$ & 3,157 & 11,788 \\
\hline 2 & Syzygium sumatranum & 8 & 1.067 & 19,048 & 0,273 & 18,75 & $915.498,9$ & 25,521 & 63,318 \\
\hline 3 & Vitex pinnata & 2 & 267 & 4,762 & 0,091 & 6,25 & $192.498,2$ & 5,366 & 16,378 \\
\hline 4 & Lindera insignis & 2 & 267 & 4,762 & 0,091 & 6,25 & $197.593,8$ & 5,508 & 16,520 \\
\hline 5 & Bridelia tomentosa & 4 & 533 & 9,524 & 0,273 & 18,75 & $215.145,1$ & 5,997 & 34,271 \\
\hline 6 & Spathodea campanulata & $\begin{array}{l}1 \\
1\end{array}$ & 133 & 2,381 & 0,091 & 6,25 & $124.557,7$ & 3,472 & 12,103 \\
\hline 7 & Calophyllum tetrapterum & & 1.733 & 30,952 & 0,182 & 12,5 & 1.234 .253 & 34,407 & 77,859 \\
\hline 8 & Xylopia malayana & 4 & 533 & 9,524 & 0,091 & 6,25 & $322.717,6$ & 8,996 & 24,770 \\
\hline 9 & Pseuderanthemum sumatrense & 1 & 133 & 2,381 & 0,091 & 6,25 & $33.970,28$ & 0,947 & 9,578 \\
\hline 10 & Microcos tomentosa & 4 & 533 & 9,524 & 0,091 & 6,25 & $169.851,4$ & 4,735 & 20,509 \\
\hline \multirow[t]{2}{*}{11} & Syzygium palembanicum & 2 & 267 & 4,762 & 0,091 & 6,25 & $67.940,55$ & 1,894 & 12,906 \\
\hline & Total & 42 & 5.600 & 100 & 1,455 & 100 & 3.587 .261 & 100 & 300 \\
\hline
\end{tabular}

Tabel 5 Indeks nilai penting semai di kawasan Arboretum Sungai Gerong

\begin{tabular}{llcccccc}
\hline No & \multicolumn{1}{c}{ Jenis vegetasi } & $\mathrm{n}$ & $\mathrm{K}(\%)$ & $\mathrm{KR}(\%)$ & $\mathrm{F}(\%)$ & $\mathrm{FR}(\%)$ & $\mathrm{INP}(\%)$ \\
\hline 1 & Flagellaria indica & 2 & 1.667 & 1,639 & 0,333 & 6,67 & 8,31 \\
2 & Ischaemum cf. muticum & 4 & 3.333 & 3,279 & 0,333 & 6,67 & 9,95 \\
3 & Nephrolepis falciformis & 16 & 13.333 & 13,115 & 0,667 & 13,33 & 26,45 \\
4 & Lea indica & 8 & 6.667 & 6,557 & 0,667 & 13,33 & 19,89 \\
5 & Alpinia zerumbet & 8 & 6.667 & 6,557 & 0,333 & 6,67 & 13,22 \\
6 & Cyclosorus interruptus & 15 & 12.500 & 12,295 & 0,333 & 6,67 & 18,96 \\
7 & Cayratia trifolia & 13 & 10.833 & 10,656 & 0,333 & 6,67 & 17,32 \\
8 & Ludwigia octovalvis & 12 & 10.000 & 9,836 & 0,333 & 6,67 & 16,50 \\
9 & Arundo donax & 19 & 15.833 & 15,574 & 0,333 & 6,67 & 22,24 \\
10 & Scleria ciliaris & 12 & 10.000 & 9,836 & 0,333 & 6,67 & 16,50 \\
11 & Ludwigia octovalvis subsp. Sessiliflora & 8 & 6.667 & 6,557 & 0,333 & 6,67 & 13,22 \\
12 & Cinnamomum iners & 4 & 3.333 & 3,279 & 0,333 & 6,67 & 9,95 \\
13 & Breynia oblongifolia & 1 & 833 & 0,820 & 0,333 & 6,67 & 7,49 \\
\hline & & 122 & 101.667 & 100 & 5,000 & 100,00 & 200,00 \\
\hline
\end{tabular}




\section{Indeks Nilai Penting (INP)}

Tingginya nilai INP suatu vegetasi dapat memperlihatkan pentingnya peranan suatu spesies vegetasi dalam suatu ekosistem (Facrul 2012). Hasil hitungan INP didapatkan bahwa jenis Spathodea campanulata yang tertinggi pada tingkat vegetasi pohon, selanjutnya INP tingkat tiang dan pancang yang tertinggi adalah jenis Calophyllum tetrapterum. INP yang tertinggi tingkat semai adalah jenis Nephrolepis falciformis. Dengan demikian jenis-jenis tersebut merupakan penyusun dalam sistem ekosistem arboretum. Kali et al. (2015) melaporkan bahwa jenis Spathodea campanulata merupakan tumbuhan yang ditemukan pada semua kategori yaitu pohon, tiang, pancang dan semai pada kawasan konsevasi sumber mata air Desa Lasiolat, Belu Kabupaten Nusa Tenggara Timur.

Beragamnya nilai INP yang didapatkan menunjukkan bahwa faktor lingkungan eksternal dan internal sangat berpengaruh dalam pertumbuhan dan perkembangan ukuran diameter batang pohon. Nilai INP dapat menggambarkan keberadaan peran struktur vegetasi suatu tegakan hutan. Beberapa faktor alam yang mempengaruhi kondisi lingkungan yaitu substansi air, tanah, kondisi suhu, cahaya, angin, organisme dan waktu (Oosting 1956).

\section{Keanekaragaman (H'), Kemerataan (E) dan Dominansi (D)}

Hasil analisis keanekaragaman jenis pada Arboretum Sungai Gerong menunjukkan keragaman tingkat rendah dan sedang (Tabel 6).

Klasifikasi vegetasi tingkat pohon dan tiang berdasarkan indeks keragaman termasuk kategori rendah, sedangkan vegetasi tingkat pancang dan semai termasuk kategori sedang (Tabel 6). Berdasarkan hasil pengamatan yang dilakukan di Arboretum Sungai Gerong menunjukkan bahwa indeks keragaman spesies pohon tergolong rendah dibandingkan dengan di hutan alam, hal ini diduga karena kawasan Arboretum Sungai Gerong merupakan hutan koleksi yang memiliki luas tertentu dan terkontrol oleh pihak perusahaan. Mason (1980) menyatakan bahwa jika nilai $H^{\prime}$ lebih kecil dari 1 tergolong rendah, begitupun jika nilai $\mathrm{H}^{\prime}$ lebih besar 1 dan lebih kecil 3 maka kategori sedang, dan jika nilai H' lebih besar 3 kategori tinggi. Dengan demikian akan menyebabkan tingkat kompleksitas yang tinggi, hal ini karena adanya interaksi antar komponen penyusun di dalam lingkungkan tersebut. Sedangkan Indeks Kemerataan (E) dari tingkat vegetasi pohon, tiang, pancang menunjukkan tinggi dengan nilai rata-rata 0,78 0,96 (Tabel 7) sehingga dapat dikatakan bahwa sebaran jumlah jenis vegetasi yang ditemukan di Arboretum Sungai Gerong memiliki persebaran yang merata. Efendi et al. (2016) melaporkan bahwa jumlah jenis pohon di Gunung Pesagi memilik sebaran yang merata, artinya bahwa tidak ditemukan jenis pohon yang mendominasi daerah tersebut.

Nilai dominansi pada tingkat vegetasi pada lokasi penelitian menghasilkan kategori rendah (Tabel 8), berdasarkan hasil indeks dominansi bahwa tidak ada vegetasi yang dominan pada area arboretum tersebut. Gunawan et al. (2011) mengungkapkan bahwa setiap tipe ekosistem atau tipe vegetasi hutan memiliki variasi dominansi masing-masing jenis vegetasi.

Kekayaan jenis vegetasi di lokasi pengamatan menghasilkan kategori rendah (Tabel 9), hanya sedikit jenis yang ditemukan pada arboretum tersebut, hal ini diduga karena arboretum tersebut memiliki area yang terbatas sehingga memungkinkan jenis-jenis tertentu yang dapat tumbuh dan berkembang. Menurut Magurran (1988) jika nilai R lebih kecil 3,5 tergolong rendah, selanjutnya jika $\mathrm{R}$ nilai lebih besar 3,5 atau lebih kecil 5,0 maka tergolong sedang, dan jika nilai $\mathrm{R}$ diatas 5,0 maka tergolong tinggi.

Tabel 6 Keanekaragaman jenis vegetasi

\begin{tabular}{lcl}
\hline \multicolumn{1}{c}{ Klasifikasi } & Keanekaragaman $\left(\mathrm{H}^{\prime}\right)$ & Kategori \\
\hline Vegetasi pohon & 0,54 & Rendah \\
Vegetasi tiang & 1,06 & Rendah \\
Vegetasis pancang & 2,05 & Sedang \\
Vegetasi semai & 2,38 & Sedang \\
\hline
\end{tabular}

Tabel 7 Kemerataan vegetasi

\begin{tabular}{lcc}
\hline \multicolumn{1}{c}{ Klasifikasi } & Kemerataan jenis & Kategori \\
\hline Vegetasi pohon & 0,78 & Tinggi \\
Vegetasi tiang & 0,96 & Tinggi \\
Vegetasis pancang & 0,86 & Tinggi \\
Vegetasi semai & 0,93 & Tinggi \\
\hline
\end{tabular}


Tabel 8 Dominansi vegetasi

\begin{tabular}{lcc}
\hline \multicolumn{1}{c}{ Klasifikasi } & Dominansi (C) & Kategori \\
\hline Vegetasi pohon & 0,50 & Rendah \\
Vegetasi tiang & 0,33 & Rendah \\
Vegetasis pancang & 0,10 & Rendah \\
Vegetasi semai & 0,08 & Rendah \\
\hline
\end{tabular}

Tabel 9 Kekayaan jenis vegetasi

\begin{tabular}{lcc}
\hline \multicolumn{1}{c}{ Klasifikasi } & Indeks kekayaan (Dmg) & Kategori \\
\hline Vegetasi pohon & 1,61 & Rendah \\
Vegetasi tiang & 2,61 & Rendah \\
Vegetasis pancang & 2,67 & Rendah \\
Vegetasi semai & 2,50 & Rendah \\
\hline
\end{tabular}

\section{SIMPULAN}

Pada kawasan Arboretum Sungai Gerong ditemukan total 23 spesies dari 17 famili. Semai merupakan tingkat pertumbuhan jenis yang tertinggi. Nilai Indeks keanekaragaman jenis (H') tergolong sedang (stabilitas sedang), nilai indeks kemerataan (E) tergolong sedang, indeks dominansi menunjukkan rendah dan indeks kekayaan jenis tergolong rendah. Tingkat pohon jenis Spathodea campanulata dengan INP tertinggi dengan nilai lebih dari $180 \%$, vegetasi tingkat tiang dan pancang didominasi oleh jenis Calophyllum tetrapterum.

\section{DAFTAR PUSTAKA}

Cahyanto T, Chairunnisa D, Sudjarwo T. 2014. Analisis vegetasi pohon hutan alam Gunung Manglayang Kabupaten Bandung. Jurnal Istek. 8(2):145-161

Dwisutono AN, Budi SR, Istomo. 2019. Keanekaragaman tumbuhan pada tipe penggunaan lahan di Kesatuan Hidrologis Gambut (KHG) Sungai Mendahara - Batanghari, Provinsi Jambi. Media Konservasi. 24 (2) : 141-151.

Efendi M, Lailaty QI, Nudin, Rustandi U, Samsudin AD. 2016. Komposisi dan keanekaragaman flora di Gunung Pesagi, Sumatera. Prosiding Seminar Nasional Masyarakat Biodiversitas Indonensia. 2(2): 198-207.

Fachrul MF. 2007. Metode Sampling Bioekologi. Jakarta: Bumi Aksara.

Gunawan W, Basuni S, Indrawan A, Prasetyo LB, Soedjito H. 2011. Analisis komposisi dan struktur vegteasi terhadap upaya restorasi kawasan hutan Taman Nasional Gunung Gede Pangrango. JPSL. 2 (1): 93-105.

Kali FB, Kusuma Z, Leksono AS. 2015. Diversity of vegetation around the springs to support Water Resource Concervation in Belu, East Nusa Tenggara, Indonesia. JBES. 6(4):100-114.
Krebs CJ. 1989. Ecologycal Methodology. Columbia: Harper Collins Publishers

Locky DA, Bayley SE. 2006. Plant diversity, composition, and rarity in the southern boreal peatlands of Manitoba, Canada. Can J bot. 84:940955.

Ludwig JA, Reynolds JF. 1988. Statistical Ecology. USA: John Willey \& Sons.

Magurran AE. 1988. Ecological Diversity and Its Measurement. USA: Chapman and Hall.

Mason CF. 1980. Ecology. Second edition. New York: Longman inc.

Misra KC. 1980. Manual of Plant Eco-logy. Second Edition. New Delhi: Oxford \& IBH Publishing Co.

Mueller-Dombois D, Ellenberg H. 1974. Aims and Methods of Vegetation Ecology. London: John Wiley $\&$ Sons.

Napolion H, Sribudiani E, Arlita T. 2015. Pemahaman pengunjung terhadap arti dan fungsi Arboretum Universitas Riau. Jom Faperta. 2(2):1-11.

Odum EP. 1971. Fundamentals of Ecology. London: WB. Saunders Co.

Oktaviani SI, Hanum L, Negara Z. 2017. Analisis vegetasi di Kawasan Terbuka Hijau Industri Gasing. Jurnal Penelitian Sains. 19(3):124-131.

Oosting HJ. 1956. The Study of Plant Communities. San Fransisco: W.H. Freeman Company.

Primack RB, Supriatna J, Indrawan M, Kramadibrata P. 1998. Biologi Konservasi. Jakarta: Yayasan Obor Indonesia.

Sidiyasa K. 2009. Sturktur dan komposisi tegakan serta keanekaragamannya di Hutan Lindung Sungai Wain, Balikpapan, Kalimantan Timur. Jurnal Penelitian Hutan dan Konservasi Alam. 1(6):79-93

Soerianegara I, Indrawan A. 2016. Ekologi Hutan Indonesia. Bogor: Laboratorium Ekologi Hutan, Fakultas Kehutanan IPB.

Suhendang E. 2002. Pengantar Ilmu Kehutanan. Bogor: Fakultas Kehutanan IPB. 